\title{
Protection of Victim's Right - The Most Serious Agenda to Be Tabled under the Criminal Justice System
}

\author{
Dr. Daisy Changmai
}

\begin{abstract}
As Martin Luther quotes - "nothing good ever comes of violence". Violence always results in various sufferings and those who suffer can rightly be termed as victims. Every violence be it physical, mental, or sexual, leaves an adverse effect on the victims. Reportedly, women and children are the common targets in any kinds of violence.In the present scenario where the rights of the accused are getting prominence under the criminal justice system, a victim should also receive considerable significance in their right to access to justice. Very often victims express their dissatisfaction for not getting proper attention as well as unsympathetic treatment during the criminal trial. On many occasion, rights of the victims are left unrepresented, as a result, majority stakeholders are deprived of their basic human right and those who show little courage to fight for the justice receives horrific experience from all corners. The Supreme Court of India assumed a stellar role through its rulings in protecting the right ofthevictims but has to make some pragmatic approach rather than an idealistic one. The international human right movement under the patronage of the United Nations has made tremendous progress to meet the challenges and raising awareness about victim's rights. Similarly, the International Criminal Court advances an innovative system of justice by taking into account the rights of victims. Adoption of the Rome Statute by the International Criminal Court embarks some ray of hope to the aspects of the victim's right.
\end{abstract}

Index Terms - Violence, Victim, Protection, Atrocity, Criminal Justice System.

\section{INTRODUCTION}

Violence is most endemic to society at all ages. It is an unwelcome phenomenon ever since the long run of civilisation. Violence be it minor or grave, threat or use physical force by a person or group of persons against another person or group of person causes injury, to the person or property. All these persons who experience injury, loss, hardship due to violence are the victims. Froma broader perspective, violence starts with the physical application of force and resulted in numerous victims as its end products. Very often, it is found that women and children are more vulnerable to victimization than others. They are subjected to violence right from their home when they are in the mother's womb and that continues even after birth. Instances of victimisation of women and children are relentless and very wide across the world. The real statistics of crime victim

Dr. Daisy Changmai, Department of Law, National Law University and Judicial Academy, Assam, Amingaon, Kamrup (R), Guwahati - 781031, India cannot be drawn because many cases go unreported due to the apathy of the prevailing system of justice delivery. A victim of crime or violence entails supports from all corners be it psychological, social or legal. They need encouragement in re-establishing themselves in the normal social life and proper aid in punishing the perpetrator.

The right of victims is the most debatable issue since long. In the present day context, where there is a transitional change of the traditional view of the criminal justice system as well as the victim's condition, a continuous effort required to be made to facilitate the victims with their basic rights.Hence, much emphasis has to lay down on the rights of victim by reforming the criminal jurisprudence. Through this paper, the researcherattempts to put a light on the issue of the need for the protection right of the victims in general and also meant to highlight the impact of legislative measures available to protect the victim's right in particular.

The method adopted in the present work is primarily doctrinal and analytical. The work is based on analysis of relevant case laws, statutes, and legal opinions by applying logical propositions and reasoning.

\section{VICTIM - IMPACTS OF VICTIMISATION:}

The expression victim refers to any person, group etc., who suffers injury or loss in body, mind, reputation or property due to illegal activity of someone else.

The legal definition of the term 'victim' under section 2(wa) of Cr. P. C. (Amendment) Act, 2008defines as,

"a person who suffered directly or threatened physical, emotional or pecuniary harm as a result of the commission of a crime, or in the case of a victim being an institutional entity, any of the similar harm by an individual or authorised representative of another entity or group who is essentially covered under civil or constitutional law and deserves assistance by the criminal justice system".

A broader interpretation to the term 'victim' has been extended by the UN Declaration of Basic Principles of Justice for Victims and Abuse of Power, 1985 as,

"Victim means those who individually or collectively have suffered from harm including physical or mental injury, emotional suffering, economic loss or substantial impairment of their fundamental rights, through acts or omissions that are in violation of criminal laws operative within member states including those prescribing criminal abuse of power. ${ }^{1}$

\footnotetext{
${ }^{1}$ Article 1 of the UN Declaration of Basic Principles of Justice for Victims and Abuse of Power, 1985
} 
The Declaration further states that - a person may be considered a victim under it regardless of whether the perpetrator is identified, apprehended, prosecuted or convicted and regardless of the familial relationship between the perpetrator and the victim. The term 'victim' also includes, where appropriate, the immediate family or the dependents of the victim and persons who have suffered harm in intervening to assist victims in distress or to prevent victimisation." 2

Moreover, the Rome Statute, one of the important documents which advance the rights of the victim states that 'victim' means natural persons who have suffered harm as a result of the commission of any crime within the jurisdiction of the court. The Statute further giving a broader interpretation to the notion of victim includes organisations or institutions that have sustained direct harm to any of their property which is dedicated to religion, education, art or science or charitable purposes and to their historic monuments, hospitals and other places and objects for humanitarian purposes. ${ }^{3}$

Thus, from the above definitions, it implies that a victim may be a natural person or a legal person who suffers physical as well as an emotional injury due to violence. There may be various types of victims as to the nature of the offence, such as victims of crime against the human body, victimsof sex discrimination, victims of sexual harassment, victims of cybercrime, victims of caste discrimination, etc. Moreover, on the basis of injury or harm, there may be three types of victims - primary, secondary and tertiary victims. Primary victims are those victims who suffer direct harm or injury as a result of illegal activity. Secondary victims, on the otherhand, suffer injury or harm as a result of injury or harm to the primary victim. Tertiary victims perhaps are those persons who experience harm or injury due to the criminal act of the offender. Secondary victims are mostly person from the family of the victim. Although there may be variation in the quantity of injury among these victims, all of them has necessarily gone through similar pain or trauma in the aftermath of violence. There may be one more category of the victim who is known as a cooperating person;they are often at risk by virtue of their association with the victim.

Violence is deep-rooted evil and pervasive in nature which leaves anadverse impact on society especially on theindividuals who suffers from it. A victim may suffer physical injury ranging from minor to fatal injuries and also incur cost and expenses of medical treatment due to such injury. But the mental torment and trauma suffered by the victim are more severe than any other effects. Thus, violence be it minor or grave, always affect the victims physically, financially and psychologically.

It is worthwhile to mention that victims can be of any sex, race, culture, religion or marital status. Reportedly, most victims are women. Women are very commonly subjected to domestic violence, sexual offences, sex discrimination, etc. A woman victim incurs maximum sufferance from psychological torment than physical or financial injury. For a

\footnotetext{
${ }^{2}$ Article 2 of the UN Declaration of Basic Principles of Justice for Victims and Abuse of Power, 1985

${ }^{3}$ Rule 85 of the Rome Statute of International Criminal Court
}

woman victim, it is very difficult to cope with the effect of violence. In our society, a victim has to face people's apathy and indifference in attitude. Many a time, victims of rape or sexual offences show great reluctance to report cases because of the social and public indignation and lack of faith in police action. While, in some cases, victims develop serious post-traumatic stress disorder.

Heather Strang in his "Repair and Revenge: Victims and Restorative Justice" analysed the expectations of a victim during the criminal proceeding, where he finds that a victim very reasonably expects to be heard his/her voice in all phases of the proceeding as well as fair and respectful treatment as it is essential for their emotional support. Apart from the retribution for their sufferance, victims usually try hard to overcome all the odds that come in the way while re-establishing in the society.

\section{VICTIM'S RIGHT RECOGNISED IN THE INTERNATIONAL SCENARIO}

The rights of the victim attract universal acclaims which led to the criminal justice reformation among the nations. Usually,the laws of the jurisdiction where the crime is investigated and prosecuted extends the right to the victim. Hence, the right of the victims may vary depending on the judicial system of states. Generally, in most of the jurisdictions, a victim is provided with the following basic rights -

1. Right to be treated with dignity, respect, and sensitivity:Victims shall be treated with courtesy,impartially, and care by the law enforcement agency and must give a fair hearing to their statements during the criminal proceedings. It is also important that throughout the process victims' privacy are to be respected in order to assure dignity.

2. Right to be informed:This right entitles the victims with the right to an intimation of the investigation as well as every event of the court proceeding.

3. Right to protection:This right extends to safeguard the victim from any kind of threats, intimidation, or retaliation before, during and after the criminal proceedings.

4. Right to receive compensation:Victims shall have the right to apply for compensation for any loss or injury to a person and property resulting fromviolence. Right to compensation of the victim includes expenses for medical treatment, loss of wages, funeral expenses etc.

5. Right to restitution:The victim shall have the right to restoration of the damage caused to his person and property.

6. Right to return of prompt personal property:Victim has got the right to return his property which was seized for the purpose of investigation etc., relating to a criminal proceeding.

7. Right to a speedy trial:The victim has got speedy disposal of the trial so as to receive fair justice and keep faith in the criminal justice system.

8. Right to enforcement of victim's rights:States are under obligation to pass some strict laws in order to enforce the 
basic rights of the victims as well as make the legal right meaningful.

Besides, the above-mentioned basic rights of the victim, a victimised woman needs special regards to her right to privacy. The plight of women victims is very serious especially victims of sexual offenceswho suffer irreparable damage and injury as a result of the crime.As such, the victim requires sympathetic and fair treatment from the law enforcing agencies. In order to provide the women victim with more inclusive justice and also free them from the fear of their identity known to others, protection of privacy right is indeed very essential.

\section{A. Victim's Right Under TheUN Declaration Of Basic Principles For Justice For Victims Of Crime And Abuse Of Power:}

Until 1980, victim's right has not got recognised in the international fora. The United Nations in 1985 adopted the Declaration of Basic Principles for Justice for Victims of Crime and Abuse of Power and assumes the responsibility to legitimise the rights of the victims at the foremost platform. The U. N. Declaration recognised four basic rights of victims-

(a) Access to justice and fair treatment includes the right to be treated with respect and compassion, right to protection of privacy and right to get redressal, right to be informed of benefits and entitlements under the law, right to be represented in the judicial and administrative process, to avoid unnecessary delay in giving relief.

(b)Right to restitution - this right entails the victims and their familyto restore their property andthe expenses incurred for any harm or loss as a result of victimisation.

(c) Compensation - the victim and their family must be paid by the State with fair compensation for violent crime that results in injury.

(d)Assistance - the victim must be provided with legal aids and support services including medical, psychological, and social assistance through a governmental, voluntary mechanism.

B. Rome Statute Of The InternationalCriminal Court And Rights Of The Victim:

Victim's right got a new paradigm through the Rome Statuteof the International Criminal Court. The Rome Statute affordsan innovative aspect in the criminal justice system by embarking on the victim's right. The Statute classified the victim's right into three categories:

(a) Right to participation: The right entitles the victim to participate in the proceeding of the court to express his/her views personally or through a legal representative at any stage of the court's proceeding and the court is bound to consider such view for fair and impartial justice. 4

(b) Right to protection:The right to protection of the victim is very significant as it ensures protection of safety, physical and psychological well-being, dignity, and privacy of victims. 5

(c) Right to reparations: This right extends to receive restitution, compensation, and rehabilitation of the victim for the injury or harm caused to the person or property. ${ }^{6}$

\section{United Nations Human Rights Office Of The High CommissionerOn Protection Of Rights Of The Victim:}

The Office of the High Commissioner (OHC) of UN Human Rights provides an extensive report on the protection of victims, witnesses, and other cooperating persons whereby the state is directed to take major responsibility to protect these group of people and to give respect to their dignity. The OHC adheres to some guiding principles in guaranteeing the rights of the victim, such as respect for confidentiality, not to do harm, not raising expectations, participatory assessment, regular risk assessment, so on and so forth.Further, the $\mathrm{OHC}$ also stipulates to take preventive measures throughout the process particularly during gathering information.

Concerning the rights of the victim, international law provides a vibrant as well as strong performa of victim protection. The United Nations senses the urgency of the protection of the victims which is visible in the above documents. In addition to it, some other documents that address the victim's rights are the International Covenant on Civil and Political Rights, 1996 (ICCPR), the Convention Elimination of All Forms of Discrimination against Women, 1979 (CEDAW), the Convention on Rights of the Child, 2002 (CRC). Moreover, regional documents like the Victims Rights and Supports Act, 2013 has a far-reaching effect on providing relief to the victim by giving appropriate recognition to the right of the victims.

Hence, it can be inferred that ever since 1985, the rights of the victims have got considerable progress in the international fora. Bundles of rights are conferred on the victims, but none of these documents has explicitly spelt about the right to privacy of the victim. It must be stated that the right to privacy is the most cherished right of a victim which is born with every human being. In the case of a victim, this right is expected to be protected and preserved during the criminal proceeding and even after it.

\section{PLIGHT OF THE VICTIM AND INDIAN LEGAL FRAMEWORK}

It is well-known fact that there is no particular law on the protection of witness and rights of the victim under Indian legal jurisprudence. As a result, victims of crime face many difficulties in claiming justice against their injury. Very often, victims or their family members have come across many barriers ranging from pressuring for withdrawal of cases to threatening to life. Especially when the accused is from a high cast or the victims belong to marginalised group dominance as to compromise or withdrawal of the cases starts right from the police forces to the society. In the given situation, many victims prefer to submit themselves before the muscle power.

\footnotetext{
${ }^{5}$ Article $68(1) \& 43(6)$ of the Rome Statute of the International Criminal Court
}

${ }^{6}$ Article 75of the Rome Statute of the International Criminal Court 
The Constitution of Indiawhich is the groundnorm for human conduct is keeping silent on the matter of victim protection. Ensuring the right to life ${ }^{7}$ is the only mandate given to the state to guarantee freedom, equality, and dignityby the Constitution.However, the Constitution casts a duty upon everyone to develop humanism. ${ }^{8}$

The Cr. P. C. (Amendment) Act, 2008 and the Criminal Law Amendment Act, 2013 made a valiant effort by redefining the rights of the victim. The recent amendment of the Cr. P. C.has brought significant changes for the victims of sexual offence in the criminal justice systemespecially, in taking a statement, medical examination of the victim, etc.The amendment also directs the State Government to prepare a scheme called 'Victim compensation scheme' in co-ordination with the Central Government for the purpose of compensation to the victim or his/her dependents. ${ }^{9}$ In order to protect women from sexual offences and to provide adequate relief, criminal laws in India has classified the offences against women into various categories, such as,

(a) Rape- punishment in terms of imprisonment for a term not less than 7 years which may extend to 10 years and also liable to fine. ${ }^{10}$

(b)Molestation -punishment in terms of imprisonment for a term of not less than 5 years which may extend to 7 years and also liable to fine. ${ }^{11}$

(c) Insult to modesty and Eve-teasing - punishmentin terms of imprisonment for a term of 1 year or with fine and imprisonment for 3 months or fine, respectively. ${ }^{12}$

(d)Sexual harassment- punishments for a term of not less than 1 year which may extend to 10 years and also liable to fine. ${ }^{13}$

(e) Importation of girl from a foreign countrypunishment for a term of 10 years and also liable to fine. ${ }^{14}$

(f) Dowry death-punishment for a term of not less than 7 years which may extend to imprisonment for life. ${ }^{15}$

(g) Cruelty by husband and relatives- punishment in terms of imprisonment for 3 years and also liable to fine. $^{16}$

(h)Bigamy- punishment with imprisonment for a term of 7 years and also liable to fine, etc. ${ }^{17}$

Some sorts of effort seem to be made by several penal statutes, namely, the Domestic Violence Act, 2005, the Protection of Children from Sexual Offences Act, 2012 and the Sexual Harassment of Women at Workplace (Prevention, Prohibition and Redressal) Act, 2013 to assure the dignity of the victims. These Acts has interpreted the term 'victim' vividly under its context and enumerates several provisions for the protection of sufferer. For example,

\footnotetext{
${ }^{7}$ Article 21 of the Constitution of India

${ }^{8}$ Article 51-A(h) of the Constitution of India

${ }^{9}$ Section 357(a) of the Criminal Amendment Act, 2013

${ }^{10}$ Section 375 and Section 376-376-E of IPC

${ }^{11}$ Section 354 of IPC

${ }^{12}$ Section 509 and Section 294 of IPC

${ }^{13}$ Section $354-$ A of IPC

${ }^{14}$ Section $366-B$ of IPC

${ }^{15}$ Section 304-B of IPC

${ }^{16}$ Section 498 -A of IPC

${ }^{17}$ Section 494 of IPC
}

theDomestic Violence Act, 2005 affords protection orders ${ }^{18}$ and the appointment of a Women Protection Officer ${ }^{19}$ to deal with the victim of domestic violence among others. Similarly, the Sexual Harassment of Women at Workplace Act, 2013 voices for the compensation of aggrieved women depending upon factors like sufferance, mental trauma, financial or other loss. ${ }^{20}$ One of the most common aspects guaranteed under all these statutes is respect for the confidentiality of the victim in any given situation. As such, all these enactments provide specific guidelines to different authority or persons that directly or indirectly involved in the criminal proceedings.

Despite all these amendments andstrong laws, the desired result is yet not achieved because of the mindset of the people as well as the reluctant attitude of the state in proper implementation. Many a time, victims or their families has to push the police or investigating authorities to investigate the case; not only that victims are also demoralised repeatedly asking about the crime scenarios. Furthermore, medical personals are directed to keep a 'safety kit' for examining rape victims which they rarely carry with them. The harrowing two finger test of a rape victim to ascertain the commission of rape which is already banned by the Supreme Court on the ground of severe violationof the right to privacy as well asthe physical and mental integrity of a rape survivor's ${ }^{21}$ is still practised by the medical practitioners. All these factors resulted in discouraging people from reporting cases of violence.

The minimum standard to be followed in case of a victim of sexual offence as suggested by the Malimath Committee ${ }^{22}$, such as the appointment of an advocate of their choice or participation of the victim in the criminal trial or financial and medical assistance or counselling by psychiatrists, etc., are rarely followed in real.We may see that there a lot of laws have been developed in the recent past, but very little change can be figured out.

Even nine years after the dreaded Nirbhaya Rape case, there is no decline in the number of cases of sexual violence; cases like kathua rape case, murder of veterinarian Dr Priyanka Reddy are examples of tragic reality.The Court has accepted the psychological trait ofthe victims of sexual violence as itattacks the entire psychology of a woman and drives her into a deep emotional disaster which cannot be remedied through compensation; further, the Court opined thatin spite of the fact that the accused might not be convicted as an end product, a victim must be supported financially during trial proceedings by providing compensation. ${ }^{23}$ This type of judgment leads us to conclude that undoubtedly the Supreme Court has taken numerous initiatives on its end in delivering justice to the victims, but somewhere the strong link to punish the perpetrator is missing in their attitude. Many a time, courts are failing to the extent of ensuring a favourable environment to the survivors of violence, particularly rape survivors, who used to face many humiliations during the court process.

\footnotetext{
${ }^{18}$ Section 18 of the Domestic Violence Act, 2005

${ }^{19}$ Section 4 of the Domestic Violence Act, 2005

${ }^{20}$ Section 15 of the Sexual Harassment of Women at Workplace (Prevention, Prohibition and Redressal) Act, 2013

${ }^{21}$ Lillu\&anr. v State of Rajasthan, (2013) 14 SCC 643

${ }^{22}$ Report of the Committee on Reforms of Criminal Justice System, 2003 available at www.mha.gov.in

${ }^{23}$ Bodhisatva Gautam v. Subhra Chakraborty, AIR 1996 SC 922
} 
Sometimes judges also held peculiar opinions about the victims especially when they belong to marginalized classes. Instances of atrocities on women in the aftermath of crime have drawn the attention of the world community towards India.After the seventy four years of independence, people in India are still judged on the basis of their caste. Caste-based dominance is the evil practice of victimisation prevailed in many of our societies. Words are insufficient to explain the plight of the victim and the family member in most of the cases. In the famous "Unnao rape case",from the beginning police refused to register the case against the accused just because he is an influential person of the state. Thereafter, threatening calls, false charges against the family of the victims become regularly faced by them and the situation finally reached heights when the victim, her uncle, and their lawyer were attempted to kill through an accident on the way to the court hearing. Recently,the Dalit woman rape case in Hathras and the brutality towards the family committed by the state police force and administration has blurred the constitutional objective of social justice once again. Unnao, Hathras are just a few numbersthat came into broad daylight whereasthe majority of cases left undocumented because of a lack of efficient mechanism of protection and safety of victims and their family members that further added the fume of resentment on democracy and fair justice into another level. Government has enacted laws to prohibit caste-based discrimination and hare crimes, ${ }^{24}$ but continuous increase in number of atrocities cases on people of schedule caste and schedule tribes raises question on the efficiency of the existing laws.

\section{CONCLUSION}

Victims' right to protection draws vital importance in any criminal justice system. The international scenario on this aspect has profoundly developed since 1985 through the U. N. Declaration of Basic Principles for Justice for Victims of Crime and Abuse of Power that can be rightly designated as the 'watershed' in the history of the rights of victims. There has been a radical change among the nations in their attitudes towards victims' right. Moreover, International Criminal Court brought a sigh of relief to the victims through the amplification of justice.Laws in India have put considerable effort to provide assistance to victims by extending compensatory relief and restoring the dignity assuring privacy of the victim through a reformation of the criminal justice system. But in reality, all these efforts are held insufficient to heal up the wounds sustained by the victims maybe because of the inefficient mechanism or inadequate handling of the situation. In this context, the role of the judiciary is very significant to mobilize peoples' opinions as well as to sensitize the criminal justice system in dispensing fair justice to the victim, but the judiciary has to go another mile to achieve the desired result. Fast-track courts become vibrant as well as a dynamic tool of justice delivery only when the traditional mindset has changed towards the victims.Too many laws have been passed after the fatal Nirbhaya incident, yet many more to learn, and until and unless it is realized by

\footnotetext{
${ }^{24}$ The Schedule Castes and Schedule Tribes (Prevention Of Atrocities) Act, 1989
}

the masses no reform in the true sense can be made. The result is very much visible to society through the repeated occurrence of brutal violence cases on the woman.

\section{REFERENCES}

[1]N. V. Paranjape - Criminology \& Penology with Victimology, Central Law Publications, 15th Edition, Allahabad: UP, 2011

[2]Dr. S. S. Srivastava - Criminology, Penology \& Victimology, Central Law Agency, 4th Edition, Allahabad:UP, 2012

[3] India: Rape victims Face Barriers to Justice- Human Rights Watch, (2017, November 8) available at https://www.hrw.org/news/2017/11/08/india-rape-victims-face-barrie rs-justice

[4]Fatima Khan, "They said no one should Cry, but then broke down - how Unnao village mourned 'rape' victims", (2020, November 22), available https://theprint.in/india/they-said-no-one-should-cry-but-then-broke-d own-how-unnao-village-mourned-rape-victim-2/549479/

[5]Annapurna Waughray, "Caste Discrimination and Minority Rights: The Case of India's Dalits", International Journal on Minority Group Rights, Koninklijke Brill NV,Leiden, 2010

\section{Author Profile:}

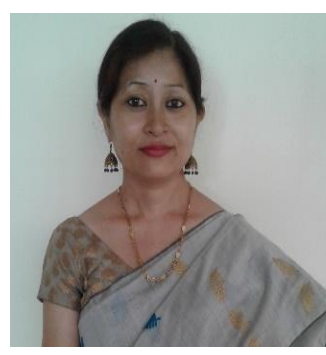

-Ph. D, UGC-NET, LL.M, MA (Political Science), B. Sc. (Honrs.).

- ISSN publication on "Need A Specific Law on Privacy in India: An Analysis" in the "Journal of Juridical and Social Science' under Regd No. ISSN: 2231-4636, October-December in 2014, Vol. 4.

- ISSN publication on "Right to Privacy under the Aegis of Right to Life and Personal Liberty" in the 'Dibrugarh University Law Journal' under Regd. No. ISSN 2348-6597, Vol. III, Annual Publication 2016.

- ISBN publication on "Violence Against Women- A Huge Threat To The Sanctity of Women" in the Book 'Violence Violence against women in India' Vol.1

- ISBN publication on "Recapturing the Traditional Knowledge and Culture of Assam with Special Reference to Silk Industry of Sualkuchi and Bell-Metal Industry of Sarthebari: A Case Study" in the book "Traditional Knowledge and Traditional Cultural Expressions: National and Community Perspectives, ISBN No. 978-81-941086-0-3, 2019

- ISBN publication on "Endemic Effect of Climate Change on the Ethnic Cuisines of Assam", published in the book "In Pursuit of Climate change", ISBN N0. 987-81-941086-2-7, 2020

- Article on "Legal Literacy: Need To Go A Long Way For The Much-Desired Impression", published in "International Journal of Legal Science and Innovation", ISSN No. 2581-9453, Vol. II-Issue I, 2020

- Article on "Rejuvenating The Right To Equality And Life Under The Paradigm Of Transformative Constitution" published in the "Annual International Journal on Analysis of Contemporary Legal Affairs", Vol. 1, 2021.

- Ph. D Research on "Right to Privacy"

- Faculty member of the "Centre for Advance Research of Corporate Law, NLU, Assam" and "Centre for Media and Sports Law, NLU, Assam". 